\title{
优化建筑施工技术 降低建筑能源损耗
}

祁如祥

江苏龙典建设集团有限公司

DOI:10.18686/bd.v1i12.1151

[摘 要] 自改革开放以来, 我国的建筑工程不断增多。众所周知, 建筑工程需要消耗大量的能源, 据了解, 建筑上的耗能量要 占总体的百分之三十。而仅就现阶段的发展来看, 我国的建筑所具有的保温隔热效果不是很理想, 功能设施也不健全, 所以应 重点解决建筑施工中的能源消耗问题。

[关键词] 施工技术; 能源损耗;优化

无论经济发展状况如何, 各个国家建筑施工的能耗在 总能耗中都占据了相当一部分比例,可见,建筑节能势在必 行。当前人们对节能建筑也达成了一致的认识,即通过从墙 体内外、运用太阳能和门窗等方面来加强围护结构的密封 性和热阻值, 从而实现节约能耗的目标。其中, 节能建筑施工 技术的合理应用显得尤其重要。

\section{1 现阶段建筑施工能耗现状}

在城市化进程不断加快的背景下, 我国的建设项目还 很多, 而这其中很多都是高能耗建筑, 浪费现象较为严重, 还 有一个棘手的问题是建筑能耗增长的实际速度要远远大过 能源的增长速度。必须要想方设法地控制这种发展趋势, 要 不然建筑工程的要求就很难得到满足,基于此,要进一步加 大施工技术的研发力度,不断优化施工技术,降低能源消耗。 但现阶段很多施工单位并没有对建筑能耗进行重视, 而是 将关注点放在如何提高企业经济利益和施工进度上。长期 处于这种情况不但会影响到企业的良性发展, 还会影响到 经济社会的可持续发展, 这就需要运用科学的方法来优化
施工技术,最大限度地降低建筑能源的消耗,使企业能够更 好的发展,以便实现经济社会的可持续发展。

\section{2 施工准备}

建筑节能指在建筑物的施工和使用阶段, 在对建筑物 的原有性能不产生影响的条件下,尽可能降低能源的损耗。 由于建筑施工中建筑物的不可逆与复杂性, 在考虑节能降 耗时,一般从建筑的门窗、外墙以及屋面等工程人手,借之以 加强其围护结构的热阻值和密闭性。施工单位首先要将节 能意识合理全面地贯彻到施工当中，四施工人员全面了解 建筑中节能损耗的紧迫性与重要性。然后再根据一定的节 能设计图纸,联系施工现场实际情况,合理地制定准确的施 工方案,不断完善管理机制。确保施工质量同时,严格根据规 定的程序进行施工, 保证施工的计划按时高效地完成。

\section{3 建筑节能降耗中的施工技术}

3.1 墙体的保温施工工作

在墙体的施工过程中, 首先要保证保温隔热材料的厚 度符合设计规范, 对于空心砖承重墙可以采取整砖平砌, 空 
心砖不能破丵, 当整砖数目不足时应该使用实心砖进行外 砌。保温板同基层还有各构造层间的连接务须牢固,不允许 脱层、空鼓或开裂现象发生。若由于预埋件或管道等原因导 致墙体预留洞口时,不能使用水泥砂浆实施填补,而应采取 实心砖砌筑。除此之外, 还应保证砌块墙体的施工质量, 对砌 块的整体性、灰缝饱满度、粉块的连接和变形协调等方面实 施严格的施工技术控制,及时地对隐蔽工程进行核查,并验 收记录。

墙体保温系统的施工是墙体节能措施的关键环节。保 温砂浆应在基层质检验收合格,屋面防水层完工,与墙体相 连的隔墙、门窗框、管线施工不破坏保温层的情况下方可施 工。施工环境温度最好大于 $5^{\circ} \mathrm{C}$, 夏季施工要注意养护和保 湿工作。保温砂浆抹灰须按设计规范依次进行,外侧砂浆工 作必须保证不出现防水、防裂、防脱落等情况,对抹灰的厚 度、表面强度等必须实施有效控制,砂浆硬化期间严禁振动 与撞击。

3.2 门窗安装的施工工作

在外墙的节能方面, 玻璃窗与门窗框的传热系数和密 闭性向来是关键的环节。为使建筑的门窗能满足节能的设 计要求,在安装时应该把握好如下几个方面:

首先,门窗框同墙体之间要做好弹性连接工作,用密封 胶来嵌填密封, 一定不能有缝隙或者使用水泥砂浆进行嵌 缝。

其次,在扇、框及推拉窗轨槽处做好密封处理工作,严禁 透气和渗水问题的出现。如果缝隙很大,可以用密封膏往里 挤注进行密封。在进行挤注密封膏或者贴密封条的工作时, 必须要清理接缝处中的灰尘杂物, 以保证作业的对象清洁 干净。

最后,在门窗与柱、梁、墙等交接地最好采用那种水泥 砂浆来进行封堵,若门窗靠室外一侧,应该结合一定的外装 修工程进行实施处理。对于变形、缝隙过大、密封不严的门 窗不能进行上墙处理, 在门窗安装过程中对于框教的垂直 度务必要进行反复的检查。

3.3 屋面保温的施工工作

建筑施工过程中往往将导热系数小、吸水率小、密度低 的保温材料装置在屋面上,来进行屋面的保温处理,以使建 筑内部温度能够满足建筑节能需要或者满足其使用功能。 目前最为常用的方法就是正铺法, 即从屋面的顶部防水层 开始一直到下部防水层, 依次进行铺设保温材料工作, 材料 选择的余地很大, 板块状有加气混凝土块、水泥聚苯板、水 泥蛭石板、聚苯乙烯板、水泥或者汸青珍珠岩板以及各种轻 骨料的混凝土板等; 无论散料、松散料,还是现场的发泡浇 筑,都在材料的选择上存在很大的空间。与之不同的是,反铺 法的施工大抵是保温层以下设置防水层, 这样可以对防水 层取到很好的保护作用,也方便日后的检查维修工作,缺点 则是工程造价过高。此外, 在屋面购置隔热措施也是建筑节
能降耗不可缺少的手段之一。

在进行屋面保温的工作时,其管理体系同样不可忽视。 建立健全质量保证体系,实施每道工艺前,一定做好技术交 底工作,把技术的要求、操作的要领、质量的要求贯彻到每 一个工作人员中去,使工作人员保证正确实施。另外严格进 行“三检”,即自检、互检和交接检。实行分段挂牌的制度,将 操作班的组长和操作者以及施工的位置、施工的日期全用 表格来进行记录, 奖惩分明。经常巡逻检查各项质量工作, 及 时发现问题,进而解决问题。

3.4 太阳能技术的应用

建筑中对于电能的消耗很大, 主要是由于使用的工具 都要靠电来实现, 而太阳能能够在一定程度上实现电的功 能,所以太阳能技术发展较为成熟,广泛应用于人民群众的 生产生活中。太阳能技术的应用原理是利用太阳能电热板, 把太阳能转化为电能, 利用一定的设备将电能输送出去转 化为机械能。利用太阳能来发电不仅能够在很大程度上节 约资源, 还是新型的绿色环保能源, 电能在转化的过程中不 会产生垃圾。只要有太阳照射的地方, 就可以对其进行转化, 投射到电路板中, 这样看来利用太阳能就可以供电给建筑 施工现场。

3.5 节水与水资源利用技术

建筑施工的过程中还需要消耗大量的水, 所以要利用 好节能技术来达到降低能源消耗的目的。众所周知,建筑工 程具有量大的特点,施工中消耗的水比较多, 其中混凝土拌 制过程中需要的水最多。由于建筑工程的不断增多,用于混 凝土拌制的水量也与之增多。另外, 混凝土在成型后水也是 不可或缺的,需要用其来进行养护,这期间所用的水比混凝 土拌制过程的用水量还要大。而我国是个缺水的国家,水资 源较为紧张, 这就需要进一步加大对于节水技术的研发力 度,这也与我国的可持续发展政策相适应。

\section{4 结束语}

据统计, 通过以上节能施工技术, 建筑能耗相对于制订 的下降了 $5 \%$,节能降耗工作取得了一定的成效。由此可见， 合理运用节能建筑施工技术, 不但可以有效加强施工全阶 段的控制, 还能降低建筑在施工和使用阶段的能源损耗,给 人民、国家、社会带来良好的经济效益。

\section{参考文献:}

[1]胡德帅.建筑施工技术中节能理念的应用研究 [J]. 建筑技术开发,2018,45(05):109.

[2]马叶朋. 基于节能降耗的工民建施工技术研究 [J]. 建材与装饰,2018,(02):29.

[3] 常建功. 建筑节能与绿色建筑技术的应用研究 [J]. 四川水泥,2018,(01):84.

[4]高皓然.超低能耗绿色建筑技术探析 [J]. 绿色环保 建材,2018,(02):16-17. 